\title{
Embryo transfer as an option to improve fertility in repeat breeder dairy cows
}

\author{
Arkadiusz Nowicki \\ Department of Animal Reproduction with Clinic, Faculty of Veterinary Medicine, \\ University of Warmia and Mazury, 10-719 Olsztyn, Poland \\ arkadiusz.nowicki@uwm.edu.pl \\ Received: August 30, $2020 \quad$ Accepted: March 8, 2021
}

\begin{abstract}
Repeat breeding is a serious reproductive disorder in dairy cattle. The causes of repeat breeding are multifactorial and there are two main mechanisms: failure of fertilisation or early embryo death, mainly due to poor quality of oocytes and an inadequate uterine environment. Many methods have been used to increase the pregnancy rate for repeat breeder cows, such as intrauterine infusion of antibacterial agents or antibiotics, hormonal treatments for oestrus synchronisation and induction of ovulation, and progesterone supplementation or induction of accessory corpus luteum; however, the results were inconsistent between studies. Embryo transfer (ET) has the capability to minimalise the effects of poor oocyte quality and unfavourable uterine environments on early embryo development during the first seven days after ovulation in repeat breeder cows, and several studies showed that ET significantly improved the pregnancy rate in this group of animals. Thus, ET can be considered an option to increase the conception rate in repeat breeder dairy cows.
\end{abstract}

Keywords: cows, repeat breeders, embryo transfer, dairy cattle.

\section{Definition and occurrence of repeat breeding}

Repeat breeding is one of the major problems in dairy cows. Repeat breeders are cows without any anatomical or infectious abnormalities that do not become pregnant after three or more breeding attempts or many artificial inseminations (AI) $(16,25)$. The incidence of repeat breeding in cattle has been reported as $9.0 \%$ in the UK (9), $24.0 \%$ in the USA (6), $10.1 \%$ in Sweden (25), 12.4\% in Poland (31), and 25.1\% in Spain (21). Repeat breeding decreases dairy profit because of wasted semen and insemination expenditure, longer inter-calving periods and higher veterinary treatment, culling and replacement costs $(6,11,38,48)$.

\section{The causes of repeat breeding}

The causes of repeat breeding are multifactorial. The failure of fertilisation or early embryo death are its two main mechanisms $(13,49)$ (Fig. 1); however, fertilisation does not seem to be the principal factor responsible for repeat breeding. Sartori et al. (55) reported that the fertilisation rates are $83 \%$ in cows and more than $90 \%$ in heifers, but these are not equalled by pregnancy rates. Fertilisation can fail because of poor oocyte quality or problems associated with $\mathrm{AI}$, one of which is insemination at an inappropriate time. Fertilisation failure can also be caused by chromosomal abnormalities, heat stress and endocrine problems induced by high milk production or unbalanced nutrition $(55,68)$. There are many studies confirming that oocytes in repeat breeder cows are poorer in quality than those in healthy cows and that it is this oocyte quality deficit that obstructs fertilisation or causes embryo mortality (19, 32, 37, 62). An example is the research by Gustafsson and Larsson (26), in which $74 \%$ of the embryos from superovulated virgin heifers on day 7 after insemination were morphologically normal compared with only $28 \%$ from superovulated repeat breeder heifers. Oocytes originating from high-yielding cows during lactation were found to develop into embryos of poorer quality than oocytes from heifers, non-lactating cows, or cows with medium milk yields $(39,55,60)$. Other researchers $(3,6)$ found the hormonal asynchrony suprabasal progesterone levels and delayed LH peaks 
around oestrus in repeat breeder cows, and these deviations prolonged the lifespan of preovulatory follicles and negatively affected the final maturation of oocytes $(3,6)$. Fertilisation failure can be also caused by inadequate oestrus detection leading to improper time of AI, incorrect AI technique, low semen quality and obstructed oviducts $(55,68,73)$.

Embryo death is the major cause of reproductive failure. Estimated ruminant embryonic mortality ranges between 20 and $50 \%(14,30)$. In highproducing dairy cows, the highest embryo loss occurs within the first week post conception $(15,56)$. The causes of early embryo mortality to day 7 post conception centre on the early embryo's inability to develop as a consequence of poor oocyte quality or an inadequate uterine environment associated with nutritional factors, heat stress, endocrine imbalance and uterine diseases $(35,63,68)$. An excess of dietary protein has a detrimental effect on the uterine environment as it raises the level of ammonia in the blood and uteri of cows (10). Heat stress has deleterious effects on oocyte maturation and the developmental competence of preimplantation embryos due to elevated maternal body temperature $(55,59,70)$. A low progesterone concentration due to its increased metabolism in high-yielding cows impoverishes the uterine environment such that it is unable to support early embryonic development $(40,69)$. Endometritis may induce embryo death by endometrial damage, bacterial toxins and inflammatory mediators such as prostaglandins, nitric oxide, reactive oxygen species and cytokines $(58,67)$; a high prevalence of subclinical endometritis (SE) has been reported in repeat breeder cows $(31,50,54)$.

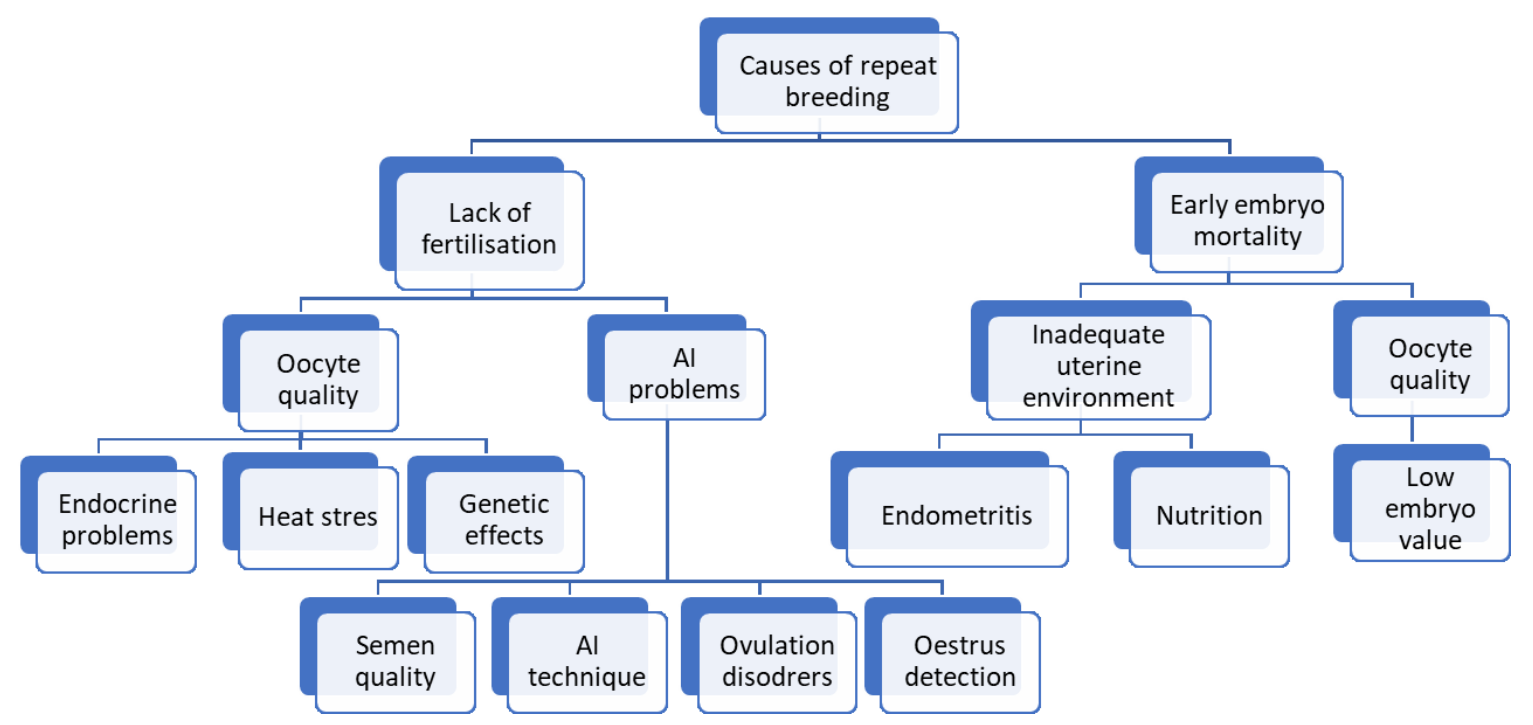

Fig. 1. Possible causes of repeat breeding

Table 1. Conception rate in repeat breeder cows after AI or ET

\begin{tabular}{|c|c|c|c|}
\hline \multirow{2}{*}{ Author } & \multicolumn{2}{|c|}{ Conception rate } & \multirow{2}{*}{ Comments } \\
\hline & AI & ET & \\
\hline Tanabe et al. 1985 (65) & - & $70 \%$ & fresh embryos transferred surgically \\
\hline Rodrigues et al. 2007 (52) & $17.9 \%$ & $41.7 \%$ & frozen-thawed embryos \\
\hline Son et al. 2007 (61) & heat $7.7 \%$ vs TAI $18.5 \%$ & $53.8 \%$ & frozen-thawed embryos; TET with CIDR and EB \\
\hline Dochi et al. 2008 (16) & $20.4 \%$ & $41.5 \%$ & frozen-thawed IVF embryos following AI \\
\hline Block et al. 2010 (7) & TAI $31.3 \%$ & $50.5 \%$ vs $27.7 \%$ & fresh embryos vs vitrified embryos (in vitro); TET \\
\hline Rodrigues et al. 2010 (53) & - & $42.9 \%$ vs $38.2 \%$ & $\begin{array}{l}\text { frozen-thawed embryos; TET with norgestomet } \\
\text { implant and eCG (cows with or without CL on day } 0 \\
\text { of the protocol) }\end{array}$ \\
\hline Canu et al. 2010 (11) & $30.0 \%$ & $52.6 \%$ & $\begin{array}{l}\text { frozen-thawed embryos }(92 \%) \text { and fresh embryos } \\
(8 \%) \text { following AI after natural heat }\end{array}$ \\
\hline Yaginuma et al. 2019 (71) & - & $46.9 \%$ & frozen-thawed IVF embryos following AI \\
\hline
\end{tabular}

$\mathrm{AI}$ - artificial insemination; CIDR - controlled internal drug release; CL - corpus luteum; EB - estradiol benzoate; eCG - equine chorionic gonadotropin; ET - embryo transfer; IVF - in vitro fertilisation; TAI - timed artificial insemination; TET - timed embryo transfer 


\section{Treatment of repeat breeder cows}

Numerous treatments have been studied to improve fertility in repeat breeder cows. Since repeat breeding may be related to subclinical endometritis, intrauterine infusions of antibiotics are commonly used for the treatment of cows in this group. However, some results were controversial $(1,20,47)$. A few studies on the treatment of repeat breeders with an intrauterine infusion of antibacterial agents or antibiotics $24 \mathrm{~h}$ after insemination resulted in varying degrees of success (23, $24,57)$. Treatment with nonsteroidal anti-inflammatory drugs at the time of AI did not influence the conception rate (27). The use of PGF $2 \alpha$ for the treatment of subclinical endometritis was also tested; however, the effects were variable $(33,41)$.

There have been many studies on hormonal treatment for ovulation disorders in repeat breeders. Stevenson et al. (64) compared the effects of double insemination during the same oestrous period and injection of $\mathrm{GnRH}$ at the time of $\mathrm{AI}$ on pregnancy rates of repeat breeder dairy cows. Gonadotropin-releasing hormone significantly increased the pregnancy rates of repeat breeders (41.6 vs 32.1\%), while double AI failed to improve them. Morgan and Lean (45) performed a meta-analysis of 40 trials on the administration of $\mathrm{GnRH}$ at $\mathrm{AI}$ and reported that the pregnancy rate for repeat breeder cows increased by $22.5 \%$. Mee et al. (43) proposed a $\mathrm{GnRH}$ injection for repeat breeder cows 12 hours after the onset of oestrus. The number of pregnant cows having received $\mathrm{GnRH}$ was higher than that of control cows administered only saline (43 vs 14.\%). Some studies revealed that the conception rate was improved in repeat breeder cows treated with Ovsynch protocols $(2,36)$.

Progesterone insufficiency in the early luteal phase is associated with embryo mortality in cows. Many methods have been tried to increase the conception rate by enhancing the endogenous progesterone level in repeat breeder cows. A number of studies have investigated the effects of progesterone supplementation on pregnancy rates. A meta-analysis by Yan et al. (72) gave very variable results. Progesterone supplementation between days 3 and 7 post insemination was beneficial only in lower fertility cows treated at spontaneous oestrus. Progesterone concentration can also be increased through induction of an accessory corpus luteum by human chorionic gonadotropin (hCG) treatment on day 5 after AI or GnRH treatment 11-14 days after it. However, the results were not consistent between studies (46, 49). Another method for supplementing progesterone after AI is the use of a progesterone-releasing intravaginal device (PRID). Villarroel et al. (66) assessed the efficacy of supplementation with exogenous progesterone for 14 days on pregnancy maintenance in inseminated repeat breeder cows but they found no positive effect of the PRIDs which they used on the pregnancy rate.

\section{ET in repeat breeder cows}

ET is widely used to increase the number of highyielding animals and create genetically superior stock. Many studies have also investigated the use of ET for improving fertility in repeat breeder cows (Table 1).

Tanabe et al. (65) compared the fertility of normal and repeat breeder cows as embryo recipients. Fresh embryos were transferred surgically into uteri, and groups were monitored for gravidity. There were no significant differences in pregnancy rates on day 60 between normal and repeat breeder recipients $(82 \%$ and $70 \%$, respectively). Rodrigues et al. (52) compared pregnancy rates in 5.693 repeat breeder Holstein cows after AI and 3.858 cows after ET. Pregnancy rates were greater after ET (41.7\%) than after AI (17.9\%).

To avoid the need for oestrus detection during ET procedure, an alternative is timed AI (TAI) in superovulated donors and timed embryo transfer (TET) in embryo recipients. Son et al. (61) evaluated pregnancy rates following controlled internal drug release (CIDR) TAI or TET protocols compared with the rates following $\mathrm{AI}$ after a single PGF $2 \alpha$ injection in the luteal phase (8-13 days after oestrus) and AI after oestrus in lactating repeat breeder dairy cows. Cows at random stages of the oestrous cycle received the CIDR device and $2 \mathrm{mg}$ estradiol benzoate (EB) (day 0), a PGF $2 \alpha$ injection at the time of CIDR removal on day 7 and a $1 \mathrm{mg}$ EB injection on day 8 for ovulation synchronisation. The cows then received TAI on day 9 , $30 \mathrm{~h}$ after the second EB injection or TET on day 16 using frozen-thawed embryos. The pregnancy rate was significantly higher in the ET group (53.8\%) than in the group for AI at detected oestrus $(18.5 \%)$ or the TAI (7.7\%) group. However, EB is banned in EU countries. Block et al. (7) investigated the proportion of cows pregnant following timed transfer of either fresh or vitrified embryos produced in vitro compared with the same proportion following timed AI. The pregnancy rate was $31.3 \%$ for cows subjected to TAI, $50.5 \%$ for cows receiving fresh embryos, and $27.7 \%$ for cows receiving vitrified embryos. Embryo transfer was particularly efficacious for infertile cows that had previously experienced several failed breeding attempts. The cows bred $>3$ times had a significantly lower rate of pregnancy success than cows bred $\leq 3$ times if the cows were inseminated, but not if the cows received a fresh or vitrified embryo. Rodrigues et al. (53) proposed a new protocol for fixed-time embryo transfer in repeat breeder cows with the addition of equine chorionic gonadotropin to the ovulation synchronisation using a norgestomet implant. Only cows with confirmed corpus luteum (CL) prior to transfer were selected as recipients. The conception rates for cows with and without CL on day 0 of the protocol were $42.9 \%$ and $38.2 \%$, respectively.

Some studies showed that embryo transfer following AI increased pregnancy rates in repeat breeder cows compared with AI alone. It is speculated that the 
higher pregnancy rate of ET following AI in repeat breeder cattle is due to the increased release of interferon tau (IFNT) from the added embryos. A greater amount of IFNT could support maternal recognition of pregnancy. Dochi et al. (16) investigated the success of AI alone or in combination with transfer of embryos produced in vivo to overcome repeat breeding problems. In repeat breeder cows, the pregnancy rate for AI alone was $30.0 \%$ compared with $52.6 \%$ after AI with embryo transfer. In the study of Yaginuma et al. (71), 1,122 repeat breeders were implanted with IVF embryos after previous AI. Implantation following insemination resulted in a pregnancy rate of $46.9 \%$ in repeat breeders. Added embryos increased the mRNA expression of interferon stimulated genes, indicating this pathway as the main mechanism leading to maintenance of embryos and resulting in a higher pregnancy rate achieved with such a protocol. These studies showed a relatively high (6.25 - $18.4 \%$ ) twin occurrence after ET following AI, while the twinning rate in dairy cows after $\mathrm{AI}$ alone was $0.3-5.0 \%(22,44)$. Twin calving has several negative consequences for both cows and calves, such as increased incidence of abortion, dystocia, higher mortality of calves around or during parturition, increased incidence of placenta retention, metabolic disorders, and decrease in milk production (22).

Apparently, ET has the potential to overcome poor oocyte and embryo quality and the deleterious effects of uterine inadequacy on early embryo development during the first seven days in repeat breeder cows. Both oocyte and embryo quality and uterine environment are adversely affected by many factors such as negative energy balance, body condition loss and metabolic diseases $(40,51,60)$, heat stress $(55,70)$ and subclinical endometritis (SE) $(58,67)$. This type of endometritis is characterised by inflammation in the absence of clinical signs and is defined by polymorphonuclear neutrophil (PMN) content exceeding 5\% in samples collected by endometrial cytobrush (42). Prevalence of SE in repeat breeder cows ranging from $12 \%$ to $53 \%$ has been reported. Several studies showed negative effects of SE on fertility after $\mathrm{AI}(4,5,8,34,54)$, and the same have been described on embryo quality in donor cows. Carvalho et al. (12) and Fernandez-Sanchez et al. (18) reported a significant reduction in the percentage of viable embryos in cows with high endometrial PMN at the onset of superovulation. Drillich et al. (17) investigated PMN dynamics in the endometrium of donor cows from AI to the time of flush (day 7) and found a significant relationship between them and the flushing outcome. Cows without PMNs at AI but with them at flush yielded the highest number of transferable embryos. Hoelker et al. (29) reported that SE affected gene expression in embryos, including the expression of genes related to membrane stability, the cell cycle and apoptosis.

However, there are no studies on the effect of SE on pregnancy outcomes after ET. It is assumed that inflammation causes an abnormal uterine environment and disrupts embryo survival (58). Hill and Gilbert (28) showed a reduction in the quality of embryos cultured in media conditioned by fluid from inflamed uteri. In the studies presented in this review $(2,3,16,19,37,39,52$, $53,61,62,64,65,66,71)$, repeat breeder cows were not differentiated regarding the occurrence of SE. It is likely that pregnancy rates would be higher in cows without SE. Endometrial cytology is considered the most reliable method for the diagnosis of SE $(5,42)$ and can be used to select recipient cows without the condition. The technique is appropriate for use in the additional studies which are needed to evaluate the correlation between the effectiveness of ET in repeat breeder cows and endometrial PMN count.

The results of the presented studies are encouraging and indicate that ET improves the pregnancy rate in repeat breeder cows by minimising the impact of poor oocyte quality and inadequate uterine environments on fertilisation and embryo development during the first 7 days after AI. Thus, ET can be considered an option to improve fertility in repeat breeder dairy cows. However, it should be noted that ET cannot be more than a course of action to improve the pregnancy rate; parturition and feeding should be still carefully organised in a way best suited to that group of animals and their uterine health requires vigilant management.

Conflict of Interests Statement: The authors declare that there is no conflict of interests regarding the publication of this article.

Financial Disclosure Statement: This study was financed by the Faculty of Veterinary Medicine of the University of Warmia and Mazury in Olsztyn.

Animal Rights Statement: None required.

\section{References}

1. Ahmadi M.R., Dehghan S.A.: Evaluation of the treatment of repeat breeder dairy cows with uterine lavage plus PGF2 $\alpha$, with and without cephapirin. Turk J Vet Anim Sci 2007, 31, 125-129.

2. Ahmed N., Kathiresan D., Ahmed F.A., Lalrintluanga K., Mayengbam P., Gali J.M.: Initiating Ovsynch on day 6 post estrus onset \pm post AI early luteal phase GnRH treatment to improve ovarian and fertility response in repeat breeding crossbred cattle. Indian J Anim Reprod 37, 2016, 5-7.

3. Båge R., Gustafsson H., Larsson B., Forsberg M., RodríguezMartínez H.: Repeat breeding in dairy heifers: follicular dynamics and estrous cycle characteristics in relation to sexual hormone patterns. Theriogenology 2002, 57, 2257-2269, doi: 10.1016/ S0093-691X(02)00840-3.

4. Barański W., Podhalicz-Dzięgielewska M., Zduńczyk S., Janowski T.: The diagnosis and prevalence of subclinical endometritis in cows evaluated by different cytologic thresholds. Theriogenology 2012, 78, 1939-1947, doi: 10.1016/j.theriogenology. 2012.07.018.

5. Barlund C.S., Carruthers T.D., Waldner C.L., Palmer C.W.: A comparison of diagnostic techniques for postpartum endometritis in dairy cattle. Theriogenology 2008, 69, 714-723, doi: 10.1016/j.theriogenology.2007.12.005. 
6. Bartlett P.C., Kirk J.H., Mather E.C.: Repeated insemination in Michigan Holstein-Friesian cattle: Incidence, descriptive epidemiology and estimated economic impact. Theriogenology 1986, 26, 309-322, doi: 10.1016/0093-691X(86)90150-0.

7. Block J., Bonilla L., Hansen P.J.: Efficacy of in vitro embryo transfer in lactating dairy cows using fresh or vitrified embryos produced in a novel embryo culture medium: J Dairy Sci 2010, 93, 5234-5242, doi: 10.3168/jds.2010-3443.

8. Bogado Pascottini O., Hostens M., Sys P., Vercauteren P., Opsomer G.: Cytological endometritis at artificial insemination in dairy cows: Prevalence and effect on pregnancy outcome. J Dairy Sci 2017, 100, 588-597, doi: 10.3168/jds.2016-11529.

9. Bulman D.C., Lamming G.E.: Milk progesterone levels in relation to conception, repeat breeding and factors influencing acyclicity in dairy cows. J Reprod Fertil 1978, 54, 447-458, doi: 10.1530/jrf.0.0540447.

10. Butler W.R.: Review: Effect of protein nutrition on ovarian and uterine physiology in dairy cattle. J Dairy Sci 1998, 81, 2533-2539, doi: 10.3168/jds.S0022-0302(98)70146-8.

11. Canu S., Boland M., Lloyd G.M., Newman M., Christie M.F., May P.J., Christley R.M., Smith R.F., Dobson H.: Predisposition to repeat breeding in UK cattle and success of artificial insemination alone or in combination with embryo transfer. Vet Rec 2010, 167, 44-51, doi: 10.1136/vr.c3544.

12. Carvalho P.D., Souza A.H., Sartori R., Hackbart K.S., Dresch A.R., Vieira L.M., Baruselli P.S., Guenther J.N., Fricke P.M., Shaver R.D., Wiltbank M.C.: Effects of deep-horn AI on fertilization and embryo production in superovulated cows and heifers. Theriogenology 2013, 80, 1074-1081, doi: 10.1016/j.theriogenology. 2013.08.008

13. De Kruif A.: Repeat breeders - a survey and study of cows upon fourth insemination. Bovine Practitioner 1976, 11, 6-8, doi: 10.21423/bovine-vol1976no11p6-8

14. Diskin M.G., Morris D.G.: Embryonic and early foetal losses in cattle and other ruminants. Reprod Dom Anim 2008, 43, 260-267, doi: 10.1111/j.1439-0531.2008.01171.x.

15. Diskin M.G., Parr M.H., Morris D.G.: Embryo death in cattle: an update. Reprod Fert Develop 2012, 24, 244-251.

16. Dochi O., Takahashi K., Hirai T., Hayakawa H., Tanisawa M., Yamamoto Y., Koyama H.: The use of embryo transfer to produce pregnancies in repeat-breeding dairy cattle. Theriogenology 2008 , 69, 124-128, doi: 10.1016/j.theriogenology.2007.09.001.

17. Drillich M., Tesfaye D., Rings F., Schellander K., Heuwieser W., Hoelker M.: Effects of polymorphonuclear neutrophile infiltration into the endometrial environment on embryonic development in superovulated cows. Theriogenology 2012, 77, 570-578, doi: 10.1016/j.theriogenology.2011.08.033.

18. Fernández Sánchez F.I., Barrio López M., Quintela Arias L.A., Becerra González J.J., Peña Martínez A.I., Martínez Bello D., García Herradón P.J., Pérez Marín C.C.: Use of endometrial cytology and metabolic profiles for selection of embryo donor cows. Span J Agric Res 2014, 12, 664-671, doi: 10.5424/sjar/2014123-4948.

19. Ferreira R.M., Ayres H., Chiaratti M.R., Ferraz M.L., Araújo A.B., Rodrigues C.A., Watanabe Y.F., Vireque A.A., Joaquim D.C., Smith L.C., Meirelles F.V., Baruselli P.S.: The low fertility of repeat breeder cows during summer heat stress is related to a low oocyte competence to develop into blastocysts. J Dairy Sci 2011, 94, 2383-2392, doi: 10.3168/jds.2010-3904.

20. Galvão K.N., Greco L.F., Vilela J.M., Sá Filho M.F., Santos J.E.P.: Effect of intrauterine infusion of ceftiofur on uterine health and fertility in dairy cows. J Dairy Sci 2009, 92, 1532-1542, doi: 10.3168/jds.2008-1615.

21. Garcia-Ispierto I., López-Gatius F.: Progesterone supplementation in the early luteal phase after artificial insemination improves conception rates in high-producing dairy cows. Theriogenology 2017, 90, 20-24, doi: 10.1016/j.theriogenology.2016.11.006.

22. Gáspárdy A., Sheridan J., Ari M., Gulyás L.: Twin Calving and Its Connection to Other Economically Important Traits in Dairy Cattle. In: Ruminants - The Husbandry, Economic and Health
Aspects, edited by M. Abubakar, InTech, London, 2018, pp. 61-81, doi: 10.5772/intechopen.72905.

23. Gümen A., Yılmazbaş-Mecitoğlu G., Keskin A., Karakaya Bilen E., Alkan A., Taşdemir U., Okut H.: The effect of intrauterine cephapirin treatment after insemination on conception rate in repeat breeder dairy cows subjected to the progesterone-based Ovsynch protocol. Turk J Vet Anim Sci, 2012, 36, 622-627, doi: 10.3906/vet-1104-13.

24. Gupta R.C., Sinha A.K., Krishnaswamy A.: Studies on the efficacy of some post-service intrauterine infusions on the conception rate of repeat breeding cattle. Theriogenology 1983, 20, 559-564, doi: 10.1016/0093-691X(83)90079-1

25. Gustafsson H., Emanuelson U.: Characterisation of the repeat breeding syndrome in Swedish dairy cattle. Acta Vet Scand 2002, 43, 115-125, doi: 10.1186/1751-0147-43-115.

26. Gustafsson H., Larsson K.: Reciprocal embryo transfer between repeat breeder and virgin heifers - an experimental model. Acta Vet Scand 1983, 24, 59-64.

27. Heuwieser W., Iwersen M., Goetze L.: Efficacy of carprofen on conception rates in lactating dairy cows after subcutaneous or intrauterine administration at the time of breeding. J Dairy Sci 2011, 94, 146-151, doi: 10.3168/jds.2010-3341.

28. Hill J., Gilbert R.: Reduced quality of bovine embryos cultured in media conditioned by exposure to an inflamed endometrium. Aust Vet J 2008, 86, 312-316, doi: 10.1111/j.1751-0813.2008.00326.x.

29. Hoelker M., Salilew-Wondim D., Drillich M., Grosse-Brinkhaus C., Ghanem N., Goetze L., Tesfaye D., Schellander K., Heuwieser W.: Transcriptional response of the bovine endometrium and embryo to endometrial polymorphonuclear neutrophil infiltration as an indicator of subclinical inflammation of the uterine environment. Reprod Fertil Dev 2012, 24, 778-793, doi: 10.1071/RD1117.

30. Humblot P.: Use of pregnancy specific proteins and progesterone assays to monitor pregnancy and determine the timing, frequencies and sources of embryonic mortality in ruminants. Theriogenology 2001, 56, 1417-1433, doi: 10.1016/S0093691X(01)00644-6.

31. Janowski T., Barański W., Łukasik K., Skarżyński D., Rudowska M., Zduńczyk S.: Prevalence of subclinical endometritis in repeat breeding cows and mRNA expression of tumor necrosis factor $\alpha$ and inducible nitric oxide synthase in the endometrium of repeat breeding cows with and without subclinical endometritis. Polish J Vet Sci 2013, 16, 693-699, doi: 10.2478/pjvs-2013-0098.

32. Kafi M., Azari M., Chashnigir O., Gharibzadeh S., Aghabozorgi Z., Asaadi A., Divar M.R.: Inherent inferior quality of follicular fluid in repeat breeder heifers as evidenced by low rates of in vitro production of bovine embryos. Theriogenology 2017, 102, 29-34, doi: 10.1016/j.theriogenology.2017.07.011.

33. Kasimanickam R., Duffield T.F., Foster R.A., Gartley C.J., Leslie K.E., Walton J.S., Johnson W.H.: A comparison of the cytobrush and uterine lavage techniques to evaluate endometrial cytology in clinically normal postpartum dairy cows. Can Vet J 2005, 46, 255-259.

34. Kasimanickam R., Duffield T.F., Foster R.A., Gartley C.J., Leslie K.E., Walton J.S., Johnson W.H.: Endometrial cytology and ultrasonography for the detection of subclinical endometritis in postpartum dairy cows. Theriogenology 2004, 62, 9-23, doi: 10.1016/j.theriogenology.2003.03.001.

35. Katagiri S., Moriyoshi M.: Alteration of the endometrial EGF profile as a potential mechanism connecting the alterations in the ovarian steroid hormone profile to embryonic loss in repeat breeders and high-producing cows. J Reprod Dev 2013, 59, 415-420, doi: 10.1262/jrd.2013-048.

36. Keskin A., Gümen A., Yılmazbaş-Mecitoğlu G., Karakaya Bilen E., Taşdemir U., Çelik Y., Okut H.: The effect of progesterone based Ovsynch protocol and GnRH treatment after artificial insemination on conception rate in repeat breeder cows. Uludag Univ J Fac Vet Med 2010, 29, 65-70.

37. Kurykin J., Waldmann A., Tiirats T., Kaart T., Jaakma Ü.: Morphological quality of oocytes and blood plasma metabolites in 
repeat breeding and early lactation dairy cows. Reprod Domest Anim 2011, 46, 253-260, doi: 10.1111/j.1439-0531.2010.01652.x.

38. Lafi S.Q., Kaneene J.B.: Epidemiological and economic study of the repeat breeder syndrome in Michigan dairy cattle. I. Epidemiological modeling. Prev Vet Med 1992, 14, 87-98, doi: 10.1016/0167-5877(92)90087-V.

39. Leroy J.L.M.R, Opsomer G., De Vliegher S., Vanholder T., Goossens L., Geldhof A., Bols P.E.J., de Kruif A., Van Soom A.: Comparison of embryo quality in high-yielding dairy cows, in dairy heifers and in beef cows. Theriogenology 2005, 64, 2022-2036, doi.org/10.1016/j.theriogenology.2005.05.003.

40. Leroy J.L.M.R., Opsomer G., Van Soom A., Goovaerts I.G.F., Bols P.E.J.: Reduced fertility in high-yielding dairy cows: are the oocyte and embryo in danger? Part I. The importance of negative energy balance and altered corpus luteum function to the reduction of oocyte and embryo quality in high-yielding dairy cows. Reprod Domest Anim 2008, 43, 612-622, doi: 10.1111/j.14390531.2007.00960.x.

41. Lima F.S., Bisinotto R.S., Ribeiro E.S., Greco L.F., Ayres H., Favoreto M.G., Carvalho M.R., Galvão K.N., Santos J.E.P.: Effects of 1 or 2 treatments with prostaglandin F2 $\alpha$ on subclinical endometritis and fertility in lactating dairy cows inseminated by timed artificial insemination. J Dairy Sci 2013, 96, 6480-6488, doi: $10.3168 /$ jds.2013-6850.

42. Madoz L.V., Giuliodori M.J., Jaureguiberry M., Plöntzke J., Drillich M., de la Sota R.L.: The relationship between endometrial cytology during estrous cycle and cutoff points for the diagnosis of subclinical endometritis in grazing dairy cows. J Dairy Sci 2013, 96, 4333-4339, doi: 10.3168/jds.2012-6269.

43. Mee M.O., Stevenson J.S., Alexander B.M., Sasser R.G. Administration of $\mathrm{GnRH}$ at estrus influences pregnancy rates, serum concentrations of LH, FSH, estradiol-17 beta, pregnancyspecific protein $\mathrm{B}$, and progesterone, proportion of luteal cell types, and in vitro production of progesterone in dairy cows. J Anim Sci 1993, 71, 185-198, doi.org/10.2527/1993.711185x.

44. Miyake Y.I., Miyoshi K., Moriya H., Matsui M., Haneda S.: Studies on the accident rate in single and multiple births in dairy cows. Jpn J Large Anim Clin 2010, 1, 5-9, doi: 10.4190/jjlac.1.5.

45. Morgan W.F., Lean I.L.: Gonadotrophin-releasing hormone treatment in cattle: A meta-analysis of the effects on conception at the time of insemination. Aust Vet J 1993, 70, 205-209, doi: 10.1111/j.1751-0813.1993.tb03304.x.

46. Nascimento A.B., Bender R.W., Souza A.H., Ayres H., Araujo R.R., Guenther J.N., Sartori R., Wiltbank M.C.: Effect of treatment with human chorionic gonadotropin on day 5 after timed artificial insemination on fertility of lactating dairy cows. J Dairy Sci 2013, 96, 2873-2882, doi: 10.3168/jds.2012-5895.

47. Oxender W.D., Seguin, B.E.: Bovine intra-uterine therapy. J Amer Vet Med Assoc 1976, 168, 217-219.

48. Perez-Marin C.C., Moreno L.M., Calero G.V.: Clinical approach to the repeat breeder cow syndrome. In: A bird's-eye view of veterinary medicine, edited by C.C. Perez-Marin, InTech, Rijeka, 2012, pp. 337-362, doi: 10.5772/31374.

49. Peters A.R., Martinez T.A., Cook A.J.C.: A meta-analysis of studies of the effect of GnRH 11-14 days after insemination on pregnancy rates in cattle. Theriogenology 2000, 54, 1317-1326, doi: 10.1016/S0093-691X(00)00438-6.

50. Pothmann H., Prunner I., Wagener K., Jaureguiberry M., de la Sota R.L., Erber R., Aurich C., Ehling-Schulz M., Drillich M.: The prevalence of subclinical endometritis and intrauterine infections in repeat breeder cows. Theriogenology 2015, 83, 1249-1253, doi: 10.1016/j.theriogenology.2015.01.013.

51. Roche J.R., Friggens N.C., Kay J.K., Fisher M.W., Stafford K.J., Berry D.P.: Invited review: body condition score and its association with dairy cow productivity, health, and welfare. J Dairy Sci 2009, 92, 5769-5801, doi: 10.3168/jds.2009-2431.

52. Rodrigues C.A., Ayres H., Ferreira R.M., Teixeira A.A., Mancilha R.F. Oliveira M.E.F., Souza A.H., Baruselli P.S.: Comparison of pregnancy rates after artificial insemination or embryo transfer in high producing repeat breeder Holstein cows. $21^{\text {st }}$ Annual meeting of the Brazilian Embryo Technology Society, Costa do Sauípe. Acta Sci Vet 2007, 35, Suppl. 3, 1255.

53. Rodrigues C.A., Teixeira A.A., Ferreira R.M., Ayres H., Mancilha R.F., Souza A.H., Baruselli P.S.: Effect of fixed-time embryo transfer on reproductive efficiency in high producing repeat-breeder Holstein cows. Anim Reprod Sci 2010, 118, 110-117, doi: 10.1016/j.anireprosci.2009.06.020.

54. Salasel B., Mokhtari A., Taktaz T.: Prevalence, risk factors for and impact of subclinical endometritis in repeat breeder dairy cows. Theriogenology 2010, 74, 1271-1278, doi.org/10.1016/ j.theriogenology.2010.05.033.

55. Sartori R., Bastos M.R., Wiltbank M.C.: Factors affecting fertilisation and early embryo quality in single- and superovulated dairy cattle. Reprod Fertil Dev 2010, 22, 151-158, doi: 10.1071/RD09221.

56. Sartori R., Sartor-Bergfelt R., Mertens S.A, Guenther J.N., Parrish J.J., Wiltbank M.C.: Fertilization and early embryonic development in heifers and lactating cows in summer and lactating and dry cows in winter. J Dairy Sci 2002, 85, 2803-2812, doi: 10.3168/jds.S0022-0302(02)74367-1.

57. Shams-Esfandabadi N., Shirazi A., Ghasemzadeh-Nava H.: Pregnancy rate following post-insemination intrauterine treatment of endometritis in dairy cattle. J Vet Med A Physiol Pathol Clin Med 2004, 51, 155-156, doi: 10.1111/j.1439-0442.2004.00618.x.

58. Sheldon I.M., Lewis G.S., LeBlanc S., Gilbert R.O.: Defining postpartum uterine disease in cattle. Theriogenology 2006, 65 1516-1530, doi: 10.1016/j.theriogenology.2005.08.021.

59. Silva C.F., Sartorelli E.S., Castilho A.C.S., Satrapa R.A., Puelker R.Z., Razza E.M., Ticianelli J.S., Eduardo H.P., Loureiro B., Barros C.M.: Effects of heat stress on development, quality and survival of Bos indicus and Bos Taurus embryos produced in vitro. Theriogenology 2013, 79, 351-357, doi: 10.1016/j.theriogenology. 2012.10.003

60. Snijders S.E.M., Dillon P., O’Callaghan D., Boland M.P.: Effect of genetic merit, milk yield, body condition and lactation number on in vitro oocyte development in dairy cows Theriogenology 2000, 53, 981-989, doi: 10.1016/S0093-691X(00)00244-2.

61. Son D.S., Choe C-Y., Cho S-R., Choi S-H., Kim H-J., Hur T-Y., Jung Y-G., Kang H-G., Kim I-H.: A CIDR-based timed embryo transfer protocol increases the pregnancy rate of lactating repeat breeder dairy cows. J Reprod Dev 2007, 53, 1313-1318, doi: $10.1262 /$ jrd.19066

62. Sood P., Zachut M., Dekel I., Dube H., Jacoby S., Moallem U.: Preovulatory follicle characteristics and oocyte competence in repeat breeder dairy cows. J Dairy Sci 2017, 100, 9372-9381, doi: 10.3168/jds.2017-12973.

63. Souza A.H., Narciso C.D., Batista E.O.S., Carvalho P.D., Wiltbank M.C.: Effect of uterine environment on embryo production and fertility in cows. Anim Reprod 2014, 11, 159-167.

64. Stevenson J.S., Call E.P., Scoby R.K., Phatak A.P.: Double insemination and gonadotropin-releasing hormone treatment of repeat-breeding dairy cattle. J Dairy Sci 1990, 73, 1766-1772, doi: 10.3168/jds.S0022-0302(90)78855-8.

65. Tanabe T.Y., Hawk H.W., Hasler J.F.: Comparative fertility of normal and repeat-breeding cows as embryo recipients. Theriogenology 1985, 23, 687-696, doi: 10.1016/0093691X(85)90203-1.

66. Villarroel A., Martino A., Bondurant R.H., Delétang F., Sischo W.M.: Effect of post-insemination supplementation with PRID on pregnancy in repeat-breeder Holstein cows. Theriogenology 2004, 61, 1513-1520, doi: 10.1016/j.theriogenology.2003.09.001.

67. Wagener K., Gabler C., Drillich M.: A review of the ongoing discussion about definition, diagnosis and pathomechanism of subclinical endometritis in dairy cows. Theriogenology 2017, 94, 21-30, doi: 10.1016/j.theriogenology.2017.02.005.

68. Walsh S.W., Williams E.J., Evans A.C.: A review of the causes of poor fertility in high milk producing dairy cows. Anim Reprod Sci 2011, 123, 127-138, doi: 10.1016/j.anireprosci.2010.12.001.

69. Wiltbank M.C., Lopez H., Sartori R., Sangsritavong S., Gümen A.: Changes in reproductive physiology of lactating dairy cows due to 
elevated steroid metabolism. Theriogenology 2006, 65, 17-29, doi: 10.1016/j.theriogenology.2005.10.003.

70. Włodarczyk R., Izdebska M., Grzanka A., Jaśkowski J.M.: Influence of heat shock on the development of bovine embryos in the early preimplantation stage. Med Weter 2007, 63, 23-28.

71. Yaginuma H., Funeshima N., Tanikawa N., Miyamura M., Tsuchiya H., Noguchi T., Iwata H., Kuwayama T., Shirasuna K., Hamano S.: Improvement of fertility in repeat breeder dairy cattle by embryo transfer following artificial insemination: possibility of interferon tau replenishment effect. J Reprod Dev 2019, 65, 223-229, doi: 10.1262/jrd.2018-121.
72. Yan L., Robinson R., Shi Z., Mann G.: Efficacy of progesterone supplementation during early pregnancy in cows: A meta-analysis. Theriogenology 2016, 85, 1390-1398, doi: 10.1016/j.theriogenology. 2015.12.027.

73. Yusuf M., Nakao T., Ranasinghe R.B., Gautam G., Long S.T., Yoshida C., Koike K., Hayashi A.: Reproductive performance of repeat breeders in dairy herds. Theriogenology 2010, 73, 1220-1229, doi: 10.1016/j.theriogenology.2010.01.016. 